\title{
Rare Thyroid Cartilage and Diaphragm Metastases from Lung Cancer Visualized on F-18 FDG-PET/CT Imaging
}

\author{
F-I 8 FDG-PET/BT Görüntülemede Akciğer Kanserinden Kaynaklanan \\ Nadir Tiroid Kıkırdağı ve Diyafram Metastazlan
}

\author{
Pelin Özcan Karal, Gonca Kara Gedik1, Oktay San'2, Orhan Özbek3 \\ ISelçuk University, Selçuklu Medical Faculty, Department of Nuclear Medicine, Selçuklu, Konya, Turkey \\ 2Selçuk University, Meram Medical Faculty, Department of Nuclear Medicine, Meram, Konya, Turkey \\ 3Selçuk University, Meram Medical Faculty, Department of Radiology, Meram, Konya, Turkey
}

\begin{abstract}
Positron emission tomography (PET) with F-1 8 fluorodeoxyglucose (FDG) has evolved as a useful imaging modality in the assessment of a variety of cancers, especially for tumor staging and post treatment monitoring. It provides metabolic information. Although, when used alone, relative lack of anatomic landmarks, is a major limitation of PET imaging, this limitation of PET imaging is overcome by the availability of integrated $\mathrm{PET} / \mathrm{CT}$ imaging. PET and CT images are acquired in one procedure, yielding fused anatomical and functional data sets. Studies with integrated PET/CT imaging have shown promising results. In this case, we present an interesting integrated PET/CT imaging in a lung cancer patient with rare, diaphragm and thyroid cartilage metastases. (MIRT 201 1;20:70-72)

Key words: PET/CT; Lung cancer; Diaphragm metastasis; Thyroid cartilage metastasis
\end{abstract}

\section{Özet}

F-1 8 Florodeoksiglukoz (FDG) ile pozitron emisyon tomografisi (PET) özellikle tümör evrelemesi ve tedavi sonrası izlem olmak üzere çeșitli kanserlerin değerlendirilmesinde yararlı bir görüntüleme yöntemi olarak gelișme göstermiștir ve metabolik bilgi sağlamaktadır. Tek bașına kullanıldı̆̆ı zaman PET görüntülemenin en önemli sınırlıı̆ı anatomik ișaretlerin rölatif eksikliği olmasına rağmen, bu sınırllık entegre PET/BT (pozitron emisyon tomografisi/bilgisayarlı tomografi) görüntülemenin kullanılabilirliği sayesinde așılmıștır. PET ve BT görüntüleri anatomik ve fonksiyonel veri setlerini birleștirmeyi sağlayan bir yöntem içinde olușturulur. Entegre PET/BT görüntüleme ile yapılan çalıșmalar umut verici sonuçlar göstermiștir. Bu olgu sunumunda nadir diyafram ve tiroid kıkırdağı metastazı olan akciğer kanserli bir hastanın ilginç PET/ BT görüntülemesi sunulmuștur. (MIRT $2011 ; 20: 70-721$

Anahtar kelimeler: PET/BT, Akciğer kanseri, diafram metastazı, tiroid kıkırdak metastazı

\section{Introduction}

Positron emission tomography (PET) with F-18 fluorodeoxyglucose (FDG) has evolved as a useful imaging modality in the assessment of a variety of cancers, especially for tumor staging and post treatment monitoring. It provides metabolic information. Although, when used alone, relative lack of anatomic landmarks, is a major limitation of PET imaging, this limitation of PET imaging is overcome by the availability of integrated positron emission tomography/computed tomography (PET/CT) imaging. PET and CT images are acquired in one procedure, yielding fused anatomical and functional data sets. In this case, we present an interesting integrated PET/CT imaging in a lung cancer patient with rare, diaphragm and thyroid cartilage metastases. 


\section{Case Report}

A 49 year-old man was referred to our institution for initial staging of non-small cell lung cancer (NSCLC). The patient underwent PET/CT imaging 60 minutes after $10 \mathrm{mCi}$ FDG injection (Figure 1). MIP image of PET/CT (a) demonstrated a $85 \times 111 \times 88 \mathrm{~mm}$ right upper lobe mass with increased FDG uptake. Left lower lobe lung nodule with a diameter of $10 \mathrm{~mm}$, paracardiac lymph node, right and left adrenal lesions, paraaortic and paraceliac lymph nodes, a $12 \mathrm{~mm}$ lesion on anterior thyroid cartilage with destruction on CT imaging (SUVmax: 6.5) $(a, b, c, d)$ and multiple bone lesions with increased FDG uptake were detected. Additionally, PET/CT showed areas of increased tracer uptake between right lower mediastinum and liver. The ill-defined lesions adjacent to the liver were missed on $\mathrm{CT}$. The exact localization of these lesions could only be determined on PET/CT imaging that could be diagnosed as metastases to the diaphragm $(a, e, f, g)$.

\section{Literature Review and Discussion}

Neither diaphragm metastasis nor thyroid cartilage metastasis was proved histopathologically, because performing

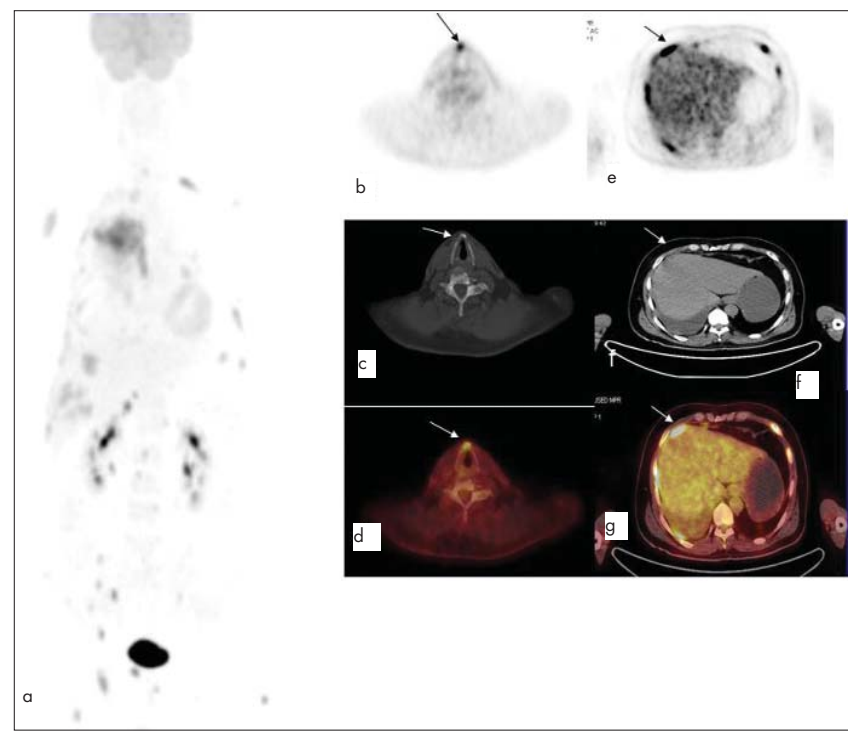

Figure 1. MIP image of PET/CT (a) demonstrated a right upper lobe mass (SUVmax: 28.0), left lower lobe lung nodule (SUVmax: 3.6), paracardiac lymph node (SUVmax: 6.2), bilateral adrenal lesions (SUVmax: 18.3-right and 4.7-left), intraabdominal lymph nodes (SUVmax: 5.6), a $12 \mathrm{~mm}$ lesion on anterior thyroid cartilage with destruction on CT imaging (SUVmax: 6.5) $(a, b, c, d)$ and multiple bone lesions with increased FDG uptake were detected. Additionally, PET/CT showed areas of increased tracer uptake between right lower mediastinum and liver. The ill-defined lesions adjacent to the liver were missed on CT. The exact localization of these lesions could only be determined on PET/CT imaging that could be diagnosed as metastases to the diaphragm $(a, e, f, g)$ biopsy in a stage IV lung cancer patient with widespread metastasis to prove diaphragm or thyroid cartilage metastasis would be a quite invasive approach. In the absence of histopathological diagnosis, normal variations in the pattern of FDG uptake, as well as physiological variants and benign pathologic conditions of FDG accumulation should not be confused with metastatic disease. It is important to recognize the increased FDG uptake in diaphragm in patients with pulmonary pathology. Increased uptake in the diaphragm and especially at the crura is mostly thought to be secondary to hyperventilation. The high FDG uptake in these situations is typically seen bilaterally (1). Unilateral FDG uptake in the diaphragm and crura was also reported (2). However, in our patient there was no bilateral or unilateral FDG uptake in the crura of the diaphragm. The infradiaphragmatic foci of increased FDG activity in the upper abdomen, poses a diagnostic dilemma on PET imaging, especially when they are asymmetrical or focal or did not conform to the expected physiological tracer distribution (3). By localizing these sites to normal fatty tissues, fused PET/CT images exclude benign nature of this uptake. The uptake pattern in thyroid cartilage may have been developed because of asymmetrical vocal cord uptake or a glottic second primary of laryngeal cancer. But these were excluded in fused PET/CT images.

Histologically, lung cancer is divided into small cell lung carcinoma (15\% to $20 \%)$ and non-small cell lung carcinoma. NSCLC comprises about $80 \%$ of all lung cancers. PET is a standard modality for both mediastinal and distant staging of NSCLC. The presence of distant metastases categorizes the patient as having stage IV disease. The most common distant metastases in NSCLC are the adrenal glands, skeleton, brain and liver (4). Unsuspected distant metastases will be detected by PET imaging in $\% 10$ of patients (5). In this case report, rare diaphragm and thyroid cartilage metastases of lung cancer were illustrated. Metastases of malignant tumors to cartilaginous tissue due to deprivation of vessels and to diaphragm are extremely rare. In a report by Wiesenthal AA et al, rare thyroid cartilage metastasis in a multipl myeloma patient with diffuse osseous and extramedullary lesions was shown by fused PET/CT imaging (6). In another case report by Lee $\mathrm{KH}$ et al, isolated diaphragmatic metastasis originated from adenocarcinoma of the colon was reported (7). Although our case was already at stage IV, PET/CT could very well demonstrated rare and unexpected metastatic cancer and provided more accurate staging in a lung cancer patient. PET/CT revealed more lesions in the patient than either PET or CT alone. Additionally, it permitted the exact anatomic localization of pathological tracer uptake. 


\section{References}

1. Cook GJ, Fogelman I, Maisey MN. Normal physiological and benign pathological variants of 18-fluoro-2-deoxyglucose positron-emission tomography scanning: potential for error in interpretation. Semin Nucl Med 1996;26(4):308-314.

2. Chander S, Ergun EL, Zak IT, Zingas AP, Bloom DA, Joyrich RN, Getzen TM, Shaman M. Diaphragmatic and crural FDG uptake in hyperventilating patients: a rare pattern important to recognize. Clin Nucl Med 2004;29(5):296-299.

3. Bar-Shalom R, Gaitini D, Keidar Z, Israel O. Non-malignant FDG uptake in infradiaphragmatic adipose tissue: a new site of physiological tracer biodistribution characterised by PET/CT. Eur J Nucl Med Mol Imaging 2004;31(8):1 105-1113.
4. Reck M, Gatzemeier U. Chemotherapy in stage-IV NSCLC. Lung Cancer 2004;45(Suppl 2):217-222.

5. Pieterman RM, van Putten JW, Meuzelaar JJ, Mooyaart EL, Vaalburg W, Koëter GH, Fidler V, Pruim J, Groen HJ. Preoperative staging of non-small-cell lung cancer with positron-emission tomography. N Engl J Med 2000;343(4):254-261.

6. Wiesenthal AA, Nguyen BD. F-18 FDG PET/CT staging of multiple myeloma with diffuse osseous and extramedullary lesions. Clin Nucl Med 2007;32(10):797-801.

7. Lee KH, Yu CS, Namgung H, Kim HC, Kim JC. Isolated diaphragmatic metastasis originated from adenocarcinoma of the colon. Cancer Res Treat 2004;36(2):157-159. 